\title{
SHADOW ECONOMY IN THE CZECH REPUBLIC
}

\author{
[Stínová ekonomika České republiky] \\ Břetislav Andrlík ${ }^{1}$, Petra Stibůrková ${ }^{2}$ \\ ${ }^{1}$ Mendelova univerzita v Brně, Provozně ekonomická fakulta, Zemědělská 1, 61300 Brno \\ Email:bretislav.andrlik@mendelu.cz. \\ ${ }^{2}$ Mendelova univerzita v Brně, Provozně ekonomická fakulta, Zemédělská 1, 61300 Brno \\ Email:42647@ node.mendelu.cz.
}

\begin{abstract}
The paper deals with the problems of estimating the size of the gray economy in the Czech Republic. As a contribution is made own measurements estimate the gray economy in the Czech Republic and using Gutmann model, but with a significant change as a result of criticism of this method the authors Paldo and Hanousek. To estimate the size of the underground economy, there are countless methods, each of which is based on several assumptions and in response to these facts are subsequently subjected to criticism from professional circles. The realization of this project paper was necessary to analyze the development of the banking sector, which has been included in this article make it possible subsequently to identify and discuss the shortcomings of this method in the basic interpretation. In the conclusion, the results of other methods of processed individual authors used to measure estimate the shadow economy.
\end{abstract}

Keywords: credit card, Gutmann model, method share of currency, shadow economy.

JEL classification: $\mathrm{O} 17$

Doručeno redakci: 8.12.2016; Recenzováno: 12.1.2017; 31.1.2017; Schváleno k publikování: 1.3.2017

\section{Úvod}

Měření stínové ekonomiky, respektive odhadnutí její velikosti není jednoduchou záležitostí, což dokazuje i skutečnost, kdy odhady rozsahu stínové ekonomiky vypracované různými autory dávají často velmi protikladné výsledky. Dokonce i v př́padech, jedná-li se o srovnání mezi státy nebo na úrovni jedné země. Problematikou těchto odchylek se zabývá Fassmann (2007), který př́činy velkých odchylek spatřuje minimálně $\mathrm{v}$ těchto čtyřech základních důvodech: různí autoři vychází často z různě definované stínové ekonomiky a používají odlišné metody odhadů, rozdílné matematické vyjádření rozdílů a v neposlední řadě odhady pocházejí z různých časových období, popřípadě se při nich využívají různě kvalitní datové soubory. Tyto důvody společně $\mathrm{s}$ dalšími tedy vedou k značným kvantitativním odchylkám, které mohou vytvářet stín pochybnosti nad smyslem měření velikosti stínové ekonomiky. V současné době poslední rozsáhlou prací na toto téma je práce Bayar (2016), která se zabývá šedou ekonomikou mimo jiné i v České republice a v literárním přehledu uvádí studie zpracované na toto téma $\mathrm{v}$ posledních letech.

Metody využívané při výpočtu odhadů velikosti stínové ekonomiky lze seskupit do několika specifických př́stupů, kdy nejčastěji se člení na přímé a nepřímé. Mezi metody přímé patří metoda výběrová šetření, která se realizuje formou průzkumu mezi firmami a domácnostmi. Dále sem patří daňové audity založené na kontrolách reprezentativních vzorků daňových subjektu. Nepř́mé metody se člení na metody rozporů, metody monetární, metody trhu práce a vícefaktorové kombinované metody. V rámci tohoto př́spěvku bude využita jedna $\mathrm{z}$ nepř́mých metod, a to konkrétně metoda monetární. Monetární metoda se $\mathrm{v}$ současné době řadí mezi jedny $\mathrm{z}$ nejpoužívanějších, přičemž za základní metody lze považovat metodu poměru odložené peněžní poptávky Petera Gutmanna a transakční metodu Edgara Feigeho. 
Oba dva tito autoři využívají společnou myšlenku, že anomálie v chování monetárních proměnných jsou způsobeny stínovou ekonomikou. Dále vychází z předpokladu, že z důvodů „Zahlazení stop“ se transakce v neformální ekonomice provádějí prostřednictvím hotových peněz - jejichž pohyb lze v ekonomice jen těžce vysledovat či popsat. Z toho vyplývá, že pokud objem hotových peněz v určitém časovém úseku v ekonomice stoupne nad „,normálně pozorovanou hodnotu“, tak s vysokou pravděpodobností v systému existují činnosti stínové ekonomiky.

Cílem příspěvku je s využitím analýzy dostupných ekonomických a peněžních údajů v České republice provést vlastní měření odhadu velikosti stínové ekonomiky. K měření velikosti stínové ekonomiky bude využita Gutmannova metoda v takové podobě, jak ji definoval Gutmann sám s tím, že na základě kritických připomínek $\mathrm{k}$ této metodě bude provedena autory úprava této metody tak, aby výsledný odhad byl realističtější a fundovaně reagoval na kritiku autorů Jana Hanouska a Filipa Paldy (viz níže).

V návaznosti na stanovený cíl jsou následně diskutovány odhady velikosti stínové ekonomiky provedené jinými autory a jimi využitých metod.

\section{Výchozí vymezení metody měření velikosti odhadu stínové ekonomiky}

Odhad stínové ekonomiky v České republice je proveden od roku 1999 až do roku 2014. Metoda, která bude k předmětnému měření využita, je založena na podílu oběživa a jedná se o zmíněnou Gutmannovu metodu, která bude však upravena v souvislosti s př́mo navazující diskuzí. Při studiu odborné literatury lze nalézt odborný článek „Předem odsouzeno k neúspěchu: Měrení šedé ekonomiky tranzitivních zemí pomocí makroekonomických metod“, který v roce 2006 publikovali Jan Hanousek a Filip Palda ve vědeckém časopise Politická ekonomie v 2. čísle. V tomto článku oba poukazují na nedostatky Gutmannovi metody, kterým se autoři tohoto př́spěvku v rámci svého měření hodlají vyvarovat. Zmiňovaná kritika spočívá $\mathrm{v}$ tom, že dle autorů je tato metoda téměř nepoužitelná pro tranzitivní ekonomiky především kvůli intenzivním inovacím ve finanční sféře v průběhu transformace. Jako vysvětlení uvádějí, že počet finančních produktů ovlivňujících poptávku po penězích v nich roste mnohem rychleji než ve vyspělých ekonomikách. Je tedy zavádějící prohlašovat, že v 90. letech v České republice šedá ekonomika bujela nejvíce, a to jen na základě obrovského růstu poptávky po oběživu.

Obsah jejich kritického př́stupu lze shrnout do několika základních bodů, v první řadě poukazuje tradičně na problém spojovaný s výchozím obdobím bez šedé ekonomiky. Mezi další problémy je řazena nestabilita podílu oběživa a rychlosti peněz díky tomu, že bankovní sektor doháněl vyspělé západní země. V krátkém časovém horizontu bylo na český trh uvedeno mnoho do té doby neexistujících finančních služeb a produkti̊. Mimo to je poukazováno na motivy držení hotovosti, které se výrazně v čase měnily - nedostatek důvěry v bankovní služby na počátku transformace, který si vynutil platby v hotovosti i u legálních operací nebo období krachů bank. V dalším bodě je upozorňováno na změny v bankovních regulacích (výše minimálních povinných rezerv, pojištění vkladů aj.).

V návaznosti na výhrady směřující k závislosti na zvoleném roku „nulové“ stínové ekonomiky, a v souladu s názorem Fassmanna (2007) bude v rámci př́spěvku předpokládáno, že v roce 1993 poměr mezi hotovostí a penězi na viděnou odrážel přirozenou potřebu hotovosti pouze oficiálního sektoru a to i přes to, že v této době šedá ekonomika v České republice jistě existovala, bude v následujících výpočtech brán jako rok výchozí. 
Nejvýznamnější výtkou je Paldou a Hanouskem oprávněně kritizovaný poměr $\mathrm{C} / \mathrm{D}$ (oběživo/depozita), který se ukazuje jako nestabilní, a to především díky přechodu na bezhotovostní platební styk a nesčetně mnoho událostí a změn, které měly vliv na bankovní sektor a výši depozit. V následující části budou analyzovány významné události v bankovní sféře a jejich vliv na výši jednodenních vkladů.

\section{Bankovní sektor České republiky a vývoj peněžních agregátů}

Na základě skutečností v uvedené kritice zmíněné výše je velký důraz kladen na rozvoj bankovních služeb na českém trhu, především v důsledku využívání platebních karet a v poslední době již i bezkontaktních platebních karet. Bez diskuse nevyvratitelný důsledek tohoto rozvoje bankovního sektoru lze shledat v postupném ústupu od hotovostních plateb. Tato skutečnost se pak logicky odráží v klesající potřebě peněžního oběživa a $\mathrm{v}$ návaznosti na kritizovaný model odhadu stínové ekonomiky, by se měl změnit i optimální poměr oběživa ke vkladům.

Následující Obrázek 1, zcela jasně demonstruje narůstající oblibu bezhotovostních plateb formou platebních karet, kdy z původních 375000 kusů, které byly vydány a využívány $\mathrm{v}$ roce 1993 se jejich počet vyšplhal až k dnešním 11421038 kusům. Pokud bychom daná čísla vzali s nadsázkou, lze konstatovat, že k dnešnímu dni má každý občan České republiky více než jednu platební kartu. Mezi důvody tak markantního růstu obliby bezhotovostních plateb lze jednoznačně zařadit skutečnost, že peníze uložené na účtu jsou kdykoliv k dispozici, jelikož v dnešní době již drtivá většina obchodníků nabízí platby pomocí platebního terminálu a téměř na každém rohu je umístěn bankomat pro prŕípadný výběr hotovosti. Dalším nezpochybnitelným faktem je i vyšší bezpečnost platebních karet při odcizení či ztrátě, jelikož karty jsou chráněny PIN kódem nebo podpisovým vzorem (budeme však abstrahovat od možnosti zneužití díky novince z června 2011, kterou představují platby u obchodníků pomocí bezkontaktních karet do 500 Kč).

Obrázek 1: Vývoj počtu vydaných platebních karet v ČR v tis. Kč

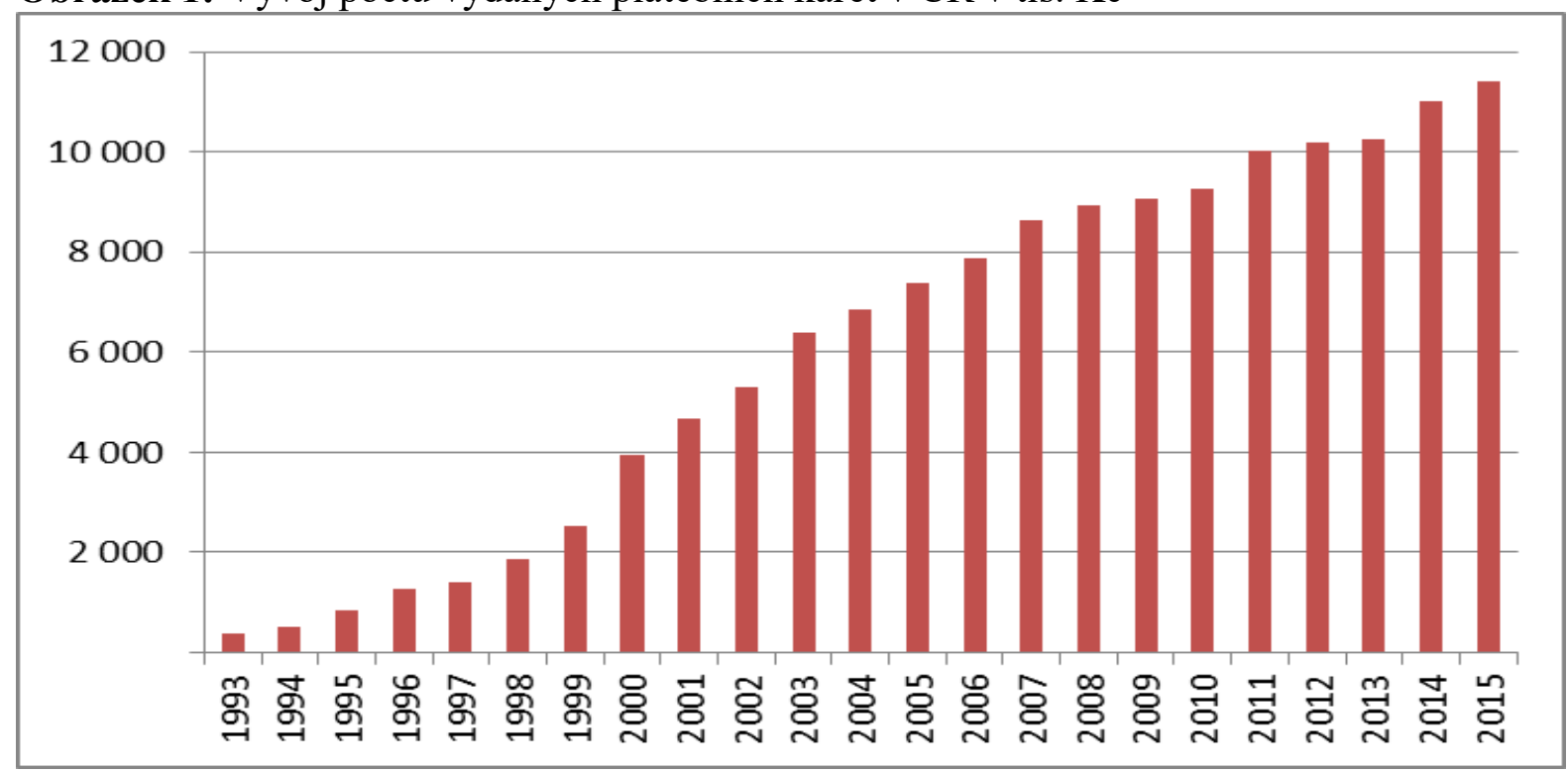

Zdroj: vlastní zpracování na základě statistik SBK (2016)

Sdružení bankovních karet každoročně zveřejňuje podrobnou statistiku týkající se platebních karet (debetních i kreditních) z hlediska vydaných kusů, počtu transakcí v automatech i jejich objemů, dále počtu plateb u obchodníků i celkovou sumu těchto operací. Z těchto údajů, které jsou však dostatečně podrobné pouze od roku 2002, vyplývají mimo jiné tyto skutečnosti: 
- počet transakcí u obchodníka se vyšplhal z 36 mil. na 789 mil, což představuje během 13 let nárůst o $2104 \%$,

- objem transakcí provedených u obchodníka, který činil v roce 2002 okolo 42 mld. Kč, se zvýšil na 409 mld. Kč, tedy rozdíl $863 \%$,

- naopak počet transakcí $\mathrm{v}$ bankomatech se nevyznačuje tak markantními změnami, jelikož v roce 2003 bylo provedeno 117 mil. transakcí a ve srovnání s rokem 2014 se jejich počet navýšil pouze o 61 mil. operací, tedy o $52 \%$,

- ovšem objem transakcí provedených bankomaty představoval ve zkoumaném období nárůst na 686 mld. Kč, tedy rozdíl $95 \%$.

Obrázek 2: Vývoj počtu a objemu transakcí platebními kartami

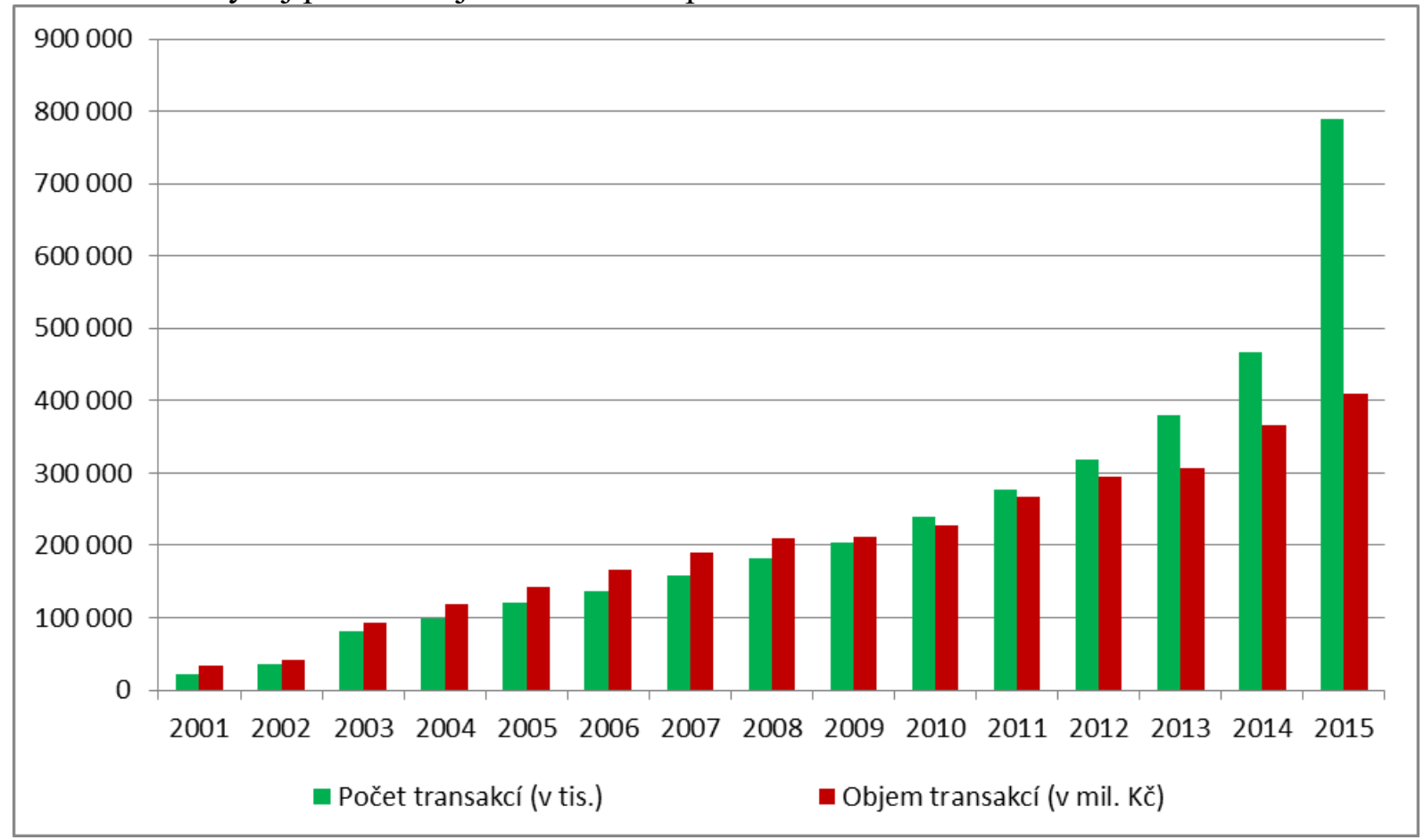

Zdroj: vlastní zpracování na základě statistiky SBK (2016)

Obrázek 2 prezentuje strmý nárůst oblíbenosti využívání platebních karet při nákupech. Všechna výše zmíněná čísla pouze dokazují, že kritika Hanouska a Paldy byla v problematice rozvoje bankovních služeb oprávněná. Neustále narůstající obliba bezhotovostních plateb se zákonitě musí projevit v odlišném optimálním poměru oběživa a jednodenních vkladů. Nutno však podotknout, že tento trend se rozmohl nikoliv v 90. letech minulého století, nýbrž až na přelomu 21. století, čili od roku 2000. Samy o sobě by byly platební karty bezvýznamné, kdybychom neměli uložené peněžní prostředky na účtech, z kterých se po platbě u obchodníka peníze strhávají. Důležitým údajem je tedy hodnota peněžních prostředků uložených ve finančních (bankovních) institucích, konkrétně vklady na požádání, které nám umožňují s penězi v nich uloženými okamžitě disponovat. Tyto peníze ve spojení s nástrojem k jejich využití (platební kartou) tedy představují významného konkurenta oběživa při peněžních transakcích. Nejstrmější nárůst lze identifikovat v roce 2015, tento nárůst je dán současnou politikou bankovních institucí, které nabízejí svým klientům výhodnější úrokovou sazbu z vkladu pouze za podmínky aktivního využívání platební karty. Z tohoto důvodu většina klientů využívá platební kartu i k nákupům za malé částky. V této souvislosti Tabulka 1 demonstruje, jak se vyvíjel stav oběživa a jednodenních vkladů (vkladů na viděnou) od roku 1993. 
Tabulka 1: Vývoj oběživa a vkladů na viděnou v mil. Kč

\begin{tabular}{|l|c|c|c|c|c|}
\hline Rok & Oběživo & $\begin{array}{c}\text { Relativní } \\
\text { změna } \\
\text { oběživa }\end{array}$ & $\begin{array}{c}\text { Vklady na } \\
\text { viděnou }\end{array}$ & $\begin{array}{c}\text { Relativní změna } \\
\text { vkladů }\end{array}$ & $\begin{array}{c}\text { Rozdíl růstu } \\
\text { v p. b. }\end{array}$ \\
\hline 2014 & 416396 & $4,9 \%$ & 2214507 & $9,8 \%$ & 4,9 \\
\hline 2013 & 396990 & $3,6 \%$ & 2017580 & $9,1 \%$ & 5,5 \\
\hline 2012 & 383031 & $5,0 \%$ & 1848613 & $8,5 \%$ & 3,5 \\
\hline 2011 & 364717 & $2,8 \%$ & 1703541 & $10,0 \%$ & 7,2 \\
\hline 2010 & 354716 & $-0,4 \%$ & 1548576 & $13,9 \%$ & 14,3 \\
\hline 2009 & 356276 & $6,0 \%$ & 1359814 & $8,1 \%$ & 2,1 \\
\hline 2008 & 336195 & $8,2 \%$ & 1258484 & $11,4 \%$ & 3,2 \\
\hline 2007 & 310602 & $11,5 \%$ & 1129637 & $15,5 \%$ & 4,0 \\
\hline 2006 & 278602 & $10,8 \%$ & 977802 & $16,7 \%$ & 5,9 \\
\hline 2005 & 251378 & $8,7 \%$ & 837699 & $8,4 \%$ & $-0,3$ \\
\hline 2004 & 231356 & $8,4 \%$ & 773026 & $13,2 \%$ & 4,8 \\
\hline 2003 & 213460 & $13,3 \%$ & 683175 & $17,9 \%$ & 4,7 \\
\hline 2002 & 188452 & $8,3 \%$ & 579216 & $58,1 \%$ & 49,8 \\
\hline 2001 & 174000 & $4,6 \%$ & 366400 & $17,1 \%$ & 12,4 \\
\hline 2000 & 166300 & $18,5 \%$ & 313000 & $13,2 \%$ & $-5,4$ \\
\hline 1999 & 140300 & $17,0 \%$ & 276600 & $6,3 \%$ & $-10,8$ \\
\hline 1998 & 119900 & $2,3 \%$ & 260300 & $-8,2 \%$ & $-10,5$ \\
\hline 1997 & 117200 & $6,1 \%$ & 283500 & $-9,0 \%$ & $-15,0$ \\
\hline 1996 & 110500 & $20,5 \%$ & 311400 & $4,8 \%$ & $-15,7$ \\
\hline 1995 & 91700 & $25,1 \%$ & 297000 & $7,6 \%$ & $-17,5$ \\
\hline 1994 & 73300 & $58,3 \%$ & 275900 & $16,6 \%$ & $-41,8$ \\
\hline 1993 & 46300 & - & 236700 & - & - \\
\hline$Z 170 j:$ & & -196 & & & \\
\hline
\end{tabular}

Zdroj: Fassmann (2003), ARAD (2016), vlastní propočty

Hodnoty oběživa a jednodenních vkladů jsou získány z veřejné databáze České národní banka ARAD a jsou rovny ročnímu průměru měsíčních konečných stavů v milionech Kč. $Z$ hodnot uvedených $\mathrm{v}$ Tabulce 2 lze konstatovat, že začátek 90. let se vyznačuje rychlejším růstem oběživa ve srovnání s vklady na viděnou. Oběživo mezi rokem 1993 a 1994 narostlo o 58,3 \%. Avšak v této souvislosti by nebylo vhodné, v návaznosti na Gutmanovu metodu, spojovat tento razantní nárůst objemu oběživa s enormním rozmachem šedé ekonomiky. Mezi logické důvody patří nejen fakt, že bankovní trh a jím poskytované služby zatím nebyly dostatečně vyvinuté a v transakcích převládala hotovostní forma plateb, ale podle Zprávy vlády o plnění státního rozpočtu ČR za 1. čtvrtletí 1994 (Poslanecká sněmovna parlamentu České republiky, 1994) se jedná i o odraz postupného obnovování potřeby oběživa po měnové odluce. Převratu $\mathrm{v}$ tomto trendu nepomohla ani bankovní krize v letech 1995 - 1998, která ve svém důsledku způsobila dokonce pokles vkladů o $9 \%$ v roce 1997. Oblibu v platbách oběživem odráží i článek Jílka (1998) Korupce, praní peněz a oběživo vydaný v Hospodářských novinách, který považuje tuto formu platby za nejbezpečnější z pohledu zajištění zaplacení.

Dynamičtější růst vkladů oproti oběživu můžeme pozorovat až v roce 2001 , kdy rozdíl činil 12,4 p. b. V následujícím roce se zvýšila důvěra v bankovní sektor především díky rozšíření pojištění vkladu z původních 400000 Kč na korunový ekvivalent 25000 eur, což ve svém důsledku znamenalo nárůst vkladů na běžných účtech o $58,1 \%$. Od tohoto roku můžeme sledovat neustálý růst, i když se vyznačuje značnou volatilitou. Jedním z důvodů kolísání je $\mathrm{v}$ roce 2003 insolvence Union banky a tím pravděpodobný pokles důvěry v bankovní sektor. Hodnota oběživa však stále roste bez ohledu na fakt, že se souběžně mnohem dynamičtěji zvyšuje hodnota i počet bezhotovostních operací a několikanásobně vzrostl počet vydaných platebních karet. Především v roce 2003 je pozorovatelný znatelný nárůst o 13,3 \%. Podle 
náměstka ředitele peněžní sekce ČNB, L. Surga (2004), jsou příčiny růstu jednoznačně ekonomické. Dosud totiž nebyl vynalezen prostředek, který by snadněji a rychleji než hotové peníze, i když za cenu určitých rizik, umožňoval realizovat obchodní operace. Hodnota oběživa tedy roste obecně na celém světě i včetně zemí, kde se bezhotovostní formy placení rozvinuly v širokém spektru a provádějí se ve značných objemech. Od roku 2006 převládá nárůst zůstatků vkladů nad oběživem. Mezi změny, které tomu napomohly, můžeme přiřadit $i$ zapojení družstevních záložen do systému pojištění v roce 2006. Výrazný pokles nebyl způsoben ani celosvětovou ekonomickou krizí, kdy jedním z opatření pro zvýšení jistoty, bylo zvýšení limitu pojistného krytí na 100000 eur a současné zkrácení výplatní lhůty Fondu pojištění vkladů na 20 pracovních dní.

Z analýzy hlavních událostí v bankovní sfére na území České republiky od roku 1993 až do současnosti a jejich následné promítnutí do chování jednotlivců formou změny poptávky po oběživu, stejně tak jako důvěry v bankovní sektor, který se projevuje mimo jiné i ochotou uložit peněžní prostředky na běžný účet, zcela jasně vyplývá, jak proměnlivé období to bylo. Všechno výše uvedené jen podtrhává kritiku Hanouska a Paldy, že využití Gutmannovy metody $\mathrm{k}$ odhadu šedé ekonomiky pro tranzitorní ekonomiku, kterou Česká republika dozajista byla a je, si vyžaduje změny.

\section{Měření odhadu stínové ekonomiky v České republice}

V rámci této kapitoly je provedeno měření odhadu velikosti stínové ekonomiky s využitím neupravené Gutmanovi metody a následně navázáno vlastním měřením autorů se zapracovanými kritickými poznatky výše zmíněných autorů z roku 2006.

\section{Metoda podílu oběživa - Gutmannova metoda}

Pro aplikaci této metody je nezbytné stanovit několik předpokladů, které budou použity při odhadu stínové ekonomiky. Při výpočtech bude předpokládáno, že veškeré aktivity stínové ekonomiky, čili neformální transakce, jsou prováděny pouze hotovostní formou plateb, tedy oběživem, a to z důvodu zakrytí pozorovatelných stop, které bezhotovostní transakce vytvářejí. Dalším předpokladem je, že rychlost obratu peněz stínové ekonomiky bude stejná jako rychlost obratu peněz oficiální ekonomiky. Pro výpočet této rychlosti se bude dále mít za to, že veškeré transakce jsou realizovány pouze peněžním agregátem M1 (součet oběživa a prostředků na běžných účtech - jednodenní vklady). Transakční rychlost peněz bude vypočtena $\mathrm{v}$ jednotlivých letech podle Soukupa (2007) jako poměr HDP v běžných cenách a peněžního agregátu M1. Současně je nutné uvést, že Český statistický úřad nezveřejňuje informace o tom, jaké procento stínové ekonomiky zahrnuje do HDP.

Výpočet odhadu stínové ekonomiky metodou poměru oběživa je následující. Esenciální veličinou, na které stojí i padá celý výpočet je určení optimálního poměru oběživa. Ten se vypočítá jako poměr oběživa v roce 1993 ve výši 46300 mil. Kč a jednodenních vkladů, které činili 236700 mil. Kč. Výsledkem je hodnota $C^{*} 0,196$ (zaokrouhleno), která představuje část jednodenních vkladů, kterým by mělo odpovídat množství oběživa v ekonomice potřebné pro formální sektor ekonomiky. To znamená, že v roce 1994 se množství jednodenních vkladů (D) 275900 mil. Kč, vynásobí základním poměrem 19,6 \% (C/D tj. oběživo/depozita) a získáme tím oběživo potřebné pro formální ekonomiku v daném roce 1994 (C*), které mělo být 54076 mil. Kč. Následný rozdíl mezi optimálním množstvím oběživa v ekonomice $\left(\mathrm{C}^{*}\right)$ a tím skutečným (C) představuje podle této metody právě oběživo, které bylo využito $\mathrm{v}$ šedé, neformální, ekonomice. To činí 19224 mil. Kč. Následným vynásobením těchto peněz používaných v šedé ekonomice transakční rychlostí peněz (V), která byla v roce 1994 rovna 3,91, získáme rozsah stínové ekonomiky, který činil 75 134,05 mil. Kč. Vyjádřeno 
v procentech, stínová ekonomika činila 5,51 \% HDP. Tento postup je stejný i ve všech následujících letech, kdy pro zjištění potřebného oběživa se bere pořád stejný optimální poměr oběživa (základního období) a to 19,6 \%, což představuje nejvíce kritizovaný aspekt metody.

Díky neustálému růstu oběživa, který podstatně převyšoval růst jednodenních vkladů, stínová ekonomika podle této metody $\mathrm{v}$ průběhu 90 . let neustále rostla a dosáhla svého maxima až v roce 2000 , kdy se vyšplhala ke $21,9 \%$. Po tomto roce pokračoval mírný propad o necelé 3 p. b., avšak v roce 2002, kdy došlo k výraznému navýšení hodnoty jednodenních vkladů, se stínová ekonomika rapidně snížila na 9,76 \%. Díky trendu neustále se zvyšujícího stavu jednodenních vkladů při stejném optimálním poměru oběživa $\mathrm{k}$ nim pak dochází k postupnému snižování odhadu stínové ekonomiky. Díky skutečnosti, že násobek deposit a základního poměru ve výši 0,196 převýšil opravdové množství oběživa, v roce 2014 nebyla žádná stínová ekonomika. Dokonce se ukazatel dostal do záporné hodnoty.

Tabulka 2: Výpočet stínové ekonomiky - metoda podílu oběživa

\begin{tabular}{|c|c|c|c|c|c|c|c|c|c|}
\hline Rok & C & D & M1 & HDP & V & C* & C-C* & $\begin{array}{c}\text { Šedá } \\
\text { ekonomika }\end{array}$ & ŠE v \% \\
\hline 1993 & 46300 & 236700 & 283000 & 1195811 & 4,23 & - & - & - & - \\
\hline 1994 & 73300 & 275900 & 349200 & 1364823 & 3,91 & 54076 & 19224 & 75134,05 & 5,51 \\
\hline 1995 & 91700 & 297000 & 388700 & 1580115 & 4,07 & 58212 & 33488 & 136132,98 & 8,62 \\
\hline 1996 & 110500 & 311400 & 421900 & 1812622 & 4,30 & 61034 & 49466 & 212520,58 & 11,72 \\
\hline 1997 & 117200 & 283500 & 400700 & 1953311 & 4,87 & 55566 & 61634 & 300450,14 & 15,38 \\
\hline 1998 & 119900 & 260300 & 380200 & 2142587 & 5,64 & 51019 & 68881 & 388174,55 & 18,12 \\
\hline 1999 & 140300 & 276600 & 416900 & 2237300 & 5,37 & 54214 & 86086 & 461983,94 & 20,65 \\
\hline 2000 & 166300 & 313000 & 479300 & 2372630 & 4,95 & 61348 & 104952 & 519533,20 & 21,90 \\
\hline 2001 & 174000 & 366400 & 540400 & 2562679 & 4,74 & 71814 & 102186 & 484583,44 & 18,91 \\
\hline 2002 & 188452 & 579216 & 767668 & 2674634 & 3,48 & 113526 & 74925 & 261048,05 & 9,76 \\
\hline 2003 & 213460 & 683175 & 896635 & 2801163 & 3,12 & 133902 & 79558 & 248544,88 & 8,87 \\
\hline 2004 & 231356 & 773026 & 1004383 & 3057660 & 3,04 & 151513 & 79843 & 243068,48 & 7,95 \\
\hline 2005 & 251378 & 837699 & 1089077 & 3257972 & 2,99 & 164189 & 87189 & 260824,86 & 8,01 \\
\hline 2006 & 278602 & 977802 & 1256403 & 3507131 & 2,79 & 191649 & 86953 & 242720,28 & 6,92 \\
\hline 2007 & 310602 & 1129637 & 1440239 & 3831819 & 2,66 & 221409 & 89193 & 237300,99 & 6,19 \\
\hline 2008 & 336195 & 1258484 & 1594679 & 4015346 & 2,52 & 246663 & 89532 & 225438,32 & 5,61 \\
\hline 2009 & 356276 & 1359814 & 1716089 & 3921827 & 2,29 & 266523 & 89752 & 205113,13 & 5,23 \\
\hline 2010 & 354716 & 1548576 & 1903292 & 3953651 & 2,08 & 303521 & 51195 & 106345,94 & 2,69 \\
\hline 2011 & 364717 & 1703541 & 2068258 & 4022410 & 1,94 & 333894 & 30823 & 59945,45 & 1,49 \\
\hline 2012 & 383031 & 1848613 & 2231644 & 4047675 & 1,81 & 362328 & 20702 & 37549,21 & 0,93 \\
\hline 2013 & 396990 & 2017580 & 2414569 & 4086260 & 1,69 & 395446 & 1544 & 2612,92 & 0,06 \\
\hline 2014 & 416396 & 2214507 & 2630904 & 4266406 & 1,62 & 434043 & -17647 & $-28617,13$ & $-0,67$ \\
\hline
\end{tabular}

Zdroj: vlastní výpočty

\section{Upravený odhad stínové ekonomiky}

$\mathrm{S}$ ohledem na oprávněnou kritiku metody podílu oběživa, která v důsledku bouřlivých změn ve vývoji ekonomiky a především bankovních služeb není ve své původní podobě vhodná pro Českou republiku, je provedena úprava ve výpočtu, čímž dojde k částečnému vyvarování se oblasti, na kterou je kladen největší stín pochybností. Konkrétně se jedná o poměr oběživa $\mathrm{k}$ jednodenním vkladům, a to $\mathrm{v}$ základním období - tedy $\mathrm{v}$ roce 1993 . Tento poměr by měl být dle původního postupu ve všech následujících letech stejný. Vlastní měření je provedeno na časové ose od roku 1999, a to z následujícího důvodu. 
Období do roku 1999 se vyznačovalo růstem oběživa, a přestože současně rostla $\mathrm{i}$ hodnota jednodenních vkladů, z informací od SBK (2016) vyplývá, že do té doby byly karty sice vydávány (a jejich množství bylo zanedbatelné), avšak jejich využití bylo u tuzemských bank pouze formou systému off-line, který umožňoval jen výběr hotovosti. Na základě těchto skutečností lze brát argumentace Paldy a Hanouska, vztahující se k rozmachu platebních karet v 90. letech, za poněkud předčasné. $Z$ tohoto důvodu bude od úpravy optimálního poměru oběživa k vkladům v období 1993 až 1998 abstrahováno. Vývoj ekonomiky v tomto období lze považovat za bouřlivý, avšak s rostoucí ekonomikou je potřeba, aby se zvyšovalo i množství oběživa, a to především v období, kdy není možno uvažovat i o jiné formě platby. Růst oběživa tedy lze považovat do jisté míry za přirozený.

Bude-li tedy předpokládáno, že poměr C/D v roce 1993 sice odrážel potřebu oběživa věrně a v souladu požadavky pro základní rok, potom po rozmachu bezhotovostních plateb, které pomalu ale jistě vytlačují hotovostní formu úhrady, je potřeba reagovat na tuto změnu.

Na základě analýzy bankovního sektoru, statistik využití platebních karet a kritiky Hanouska a Paldy, která je rozebrána výše, je provedena úprava této metody. Konkrétně se úprava bude týkat výše optimálního poměru oběživa v jednotlivých letech od roku 2001. Tento rok byl význačný nejen díky boomu využití bezhotovostní formy platby, ale taky skutečnosti, že poprvé růst jednodenních vkladů převýšil procentuální růst oběživa. Je samozřejmostí, že i v současné době je hotovost potřebná, především pro starší občany, kteří nemají důvěru a potřebnou gramotnost pro využívání alternativních způsobu plateb. Následující úprava tedy vychází z myšlenky, že růst oběživa je přirozený a rozdíl, o který převyšuje růst jednodenních vkladů růst oběživa, představuje právě odraz upřednostňování a přechodu $\mathrm{k}$ bezhotovostní formě plateb. Výsledky a výpočet je v následující Tabulce 3.

Tabulka 3: Odhad stínové ekonomiky v mil. Kč - upravená metoda podílu oběživa

\begin{tabular}{|l|c|c|c|c|c|c|c|}
\hline Rok & $\mathbf{V}$ & $\begin{array}{c}\text { Rozdíl } \\
\text { růstu } \\
\text { D a C }\end{array}$ & C/D* & C* & C-C* & ŠE v mil. Kc & ŠE v \% \\
\hline 2014 & 1,62 & 0,0487 & 0,0464 & 102643 & 313753 & 508798 & 11,93 \\
\hline 2013 & 1,69 & 0,0550 & 0,0487 & 98303 & 298687 & 505478 & 12,37 \\
\hline 2012 & 1,81 & 0,0350 & 0,0516 & 95312 & 287718 & 521853 & 12,89 \\
\hline 2011 & 1,94 & 0,0719 & 0,0534 & 91018 & 273699 & 532297 & 13,23 \\
\hline 2010 & 2,08 & 0,1432 & 0,0576 & 89148 & 265567 & 551655 & 13,95 \\
\hline 2009 & 2,29 & 0,0208 & 0,0672 & 91365 & 264910 & 605407 & 15,44 \\
\hline 2008 & 2,52 & 0,0317 & 0,0686 & 86353 & 249842 & 629093 & 15,67 \\
\hline 2007 & 2,66 & 0,0404 & 0,0709 & 80050 & 230552 & 613393 & 16,01 \\
\hline 2006 & 2,79 & 0,0589 & 0,0738 & 72209 & 206393 & 576127 & 16,43 \\
\hline 2005 & 2,99 & $-0,0029$ & 0,0785 & 65734 & 185644 & 555352 & 17,05 \\
\hline 2004 & 3,04 & 0,0477 & 0,0782 & 60484 & 170873 & 520190 & 17,01 \\
\hline 2003 & 3,12 & 0,0468 & 0,0822 & 56131 & 157329 & 491508 & 17,55 \\
\hline 2002 & 3,48 & 0,4978 & 0,0862 & 49926 & 138526 & 482637 & 18,04 \\
\hline 2001 & 4,74 & 0,1243 & 0,1716 & 62888 & 111112 & 526915 & 20,56 \\
\hline 2000 & 4,95 & $-0,0269$ & 0,1960 & 61348 & 104952 & 519533 & 21,90 \\
\hline 1999 & 5,37 & $-0,0538$ & 0,1960 & 54214 & 86086 & 461984 & 20,65 \\
\hline
\end{tabular}

Zdroj: ARAD (2016), vlastní výpočet

Základní princip výpočtu je analogický s původní metodou poměru oběživa, která je popsána výše. Rozdíl bude představovat úprava optimálního poměru oběživa od roku 2001, a to v každém následujícím roce tak, že tento poměr bude navýšen nebo snížen o rozdíl v růstu oběživa a jednodenních vkladů v jednotlivých letech. 
Jak ukazuje Tabulka 1, od roku 2001 rostla hodnota oběživa pomaleji než hodnota vkladů na viděnou, a to mimo jiné $\mathrm{z}$ již výše popisovaných prŕčcin. Za předpokladu, že tato změna $\mathrm{v}$ růstu odráží požadavky ekonomických subjektů, které upřednostňují bezhotovostní formu plateb a pro tu potřebují nikoliv oběživo, ale finanční prostředky na účtech, rozdíl bude představovat snížení potřeby oběživa. $Z$ tohoto důvodu bude poměr $C / D^{*}$ pro výpočet šedé ekonomiky $\mathrm{v}$ tomto období pozvolna snižovat. Hodnotu tohoto optimálního poměru a vývoj v čase ukazuje sloupec C/D*.

Postup úpravy optimálního poměru oběživa roce 2001 byl následující. Základní poměr z roku 1993 ve výši 0,196, u kterého je stále předpokládáno, že odráží optimální potřebu oběživa i přes uvedené výtky, byl snížen o rozdíl mezi růstem jednodenních vkladů a oběživem. Jelikož tedy oběživo zaznamenalo nižší nárůst, lze považovat za logické i snížení optimálního poměru oběživa ke vkladům 0,196 , a to o $12,43 \%$. Následný nový optimální poměr bude tedy činit 0,1716 . Tento nový poměr pro rok 2001 se použije obdobně pro odhad stínové ekonomiky tak, jak tomu bylo v původním modelu poměru oběživa. V následujících letech bude opět použit poměr z předchozího roku, který bude upraven o rozdíl růstu jednodenních vkladů a oběživa. Pouze v roce 2005 bude poměr snižován díky skutečnosti, že růst oběživa převýšil růst vkladů.

Jak vychází z výpočtů, rok 2000 se vyznačuje nejvyšším podílem stínové ekonomiky ve výši 21,9 \%, avšak od tohoto roku se ustavičně snižuje až k současným 11,93 \%, což představuje pokles o 9,97 p. b. Podle generálního ředitele Visa Europe pro Českou a Slovenskou republiku Marcela Gajdoše (Visa 2013), spočívá šedá ekonomika především v práci načerno a nehlášení př́ijmů. Za postupný pokles dle něj mohou především ekonomické podmínky a vládní úsilí. Ve studii společnosti Visa (2015), kterou publikuje ve spolupráci s expertem na šedou ekonomiku, Friedrichem Schneiderem z rakouské Univerzity Johannese Keplera, je uveden za hlavní důvod poklesu rozvoj bezkontaktních plateb a terminálů. Podle této studie zvýšení elektronických plateb o $10 \%$ sníži šedou ekonomiku o $5 \%$. Současně je nezbytné konstatovat, že provedenou úpravou se podařilo částečně odstranit určité body kritiky, avšak i přesto tento model není pro odhady stínové ekonomiky zcela věrohodný. Už jen pouhý předpoklad, že veškerá stínová ekonomika je prováděna pouze hotovostní formou úhrad, není zcela realistický.

\section{Srovnání výsledků odhadů stínové ekonomiky}

Na základě výpočtů provedených v kapitolách výše se nyní zaměříme na diskuzi a komparaci dosažených výsledků metody poměru oběživa.

Obrázek 3: Srovnání výsledků odhadu šedé ekonomiky v \%

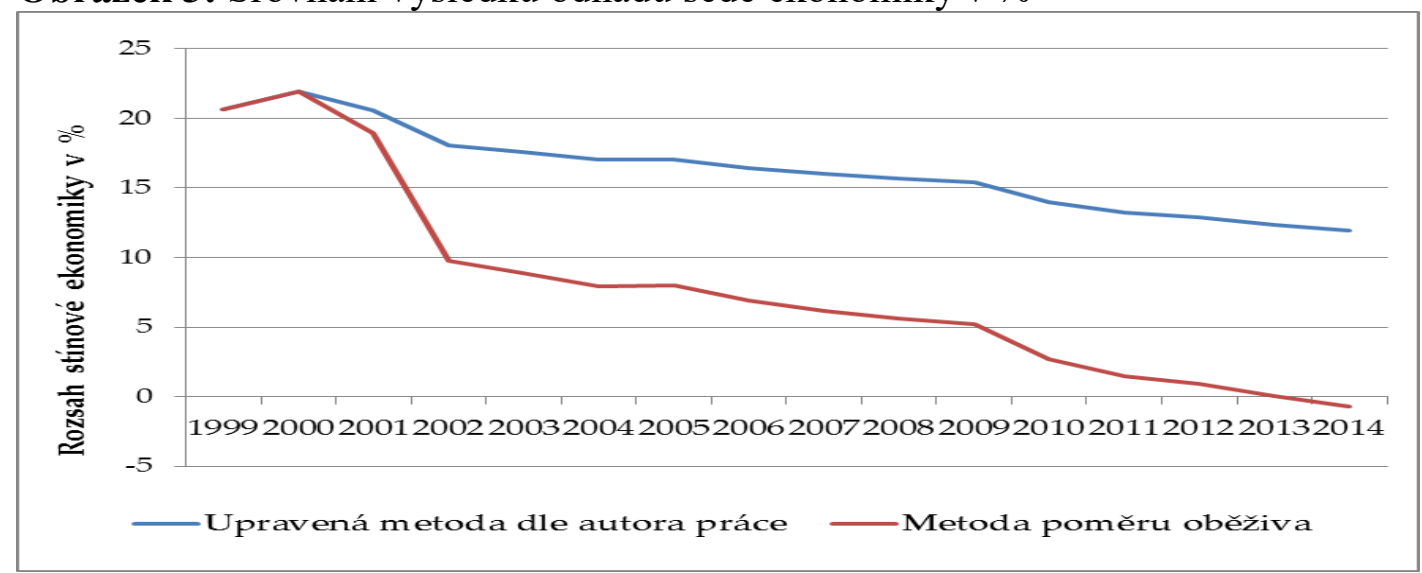

Zdroj: vlastní práce 
Jak je patrné, rozdíly ve výsledcích dosahují v roce 2014 až 12,6 p. b. Dokonce původní metoda naznačuje úplné vymizení stínové ekonomiky, což je zcela v rozporu s ekonomickou realitou. Za těmito neustále se zvyšujícími rozdíly stojí především strmý nárůst peněžních prostředků na běžných účtech a ostatních formách účtů, které umožňují okamžité využití peněžních prostředků.

Největší skok v hodnotě vkladů na viděnou byl v roce 2002, kdy z původních 366400 mil. Kč, které byly v bankách v roce 2001, se jejich stav vyšplhal až na 579216 mil. Kč, což je růst o 58,1 \%. Podle záznamu z jednání bankovní rady ČNB ze dne 27. února 2003 je jednou z prríčin takového navýšení růst úvěrů, který v tomto období poskytly banky domácnostem. Další důvod lze spatřit skutečnosti, že objem peněz na netermínovaných vkladech domácností se rychle zvyšuje i díky úrokové neatraktivnosti spoření u termínovaných vkladů, a dále hraje důležitou roli i to, že pro obyvatelstvo jsou peníze na běžných účtech likvidní a ve srovnání s ponecháním doma se jejich uložení u bank považuje také jako podstatně méně rizikové. Za zmínku stojí i možné zvýšení důvěry v bankovní sektor především díky rozšiřrení pojištění vkladu z původních $400000 \mathrm{Kč} \mathrm{na} \mathrm{korunový} \mathrm{ekvivalent} 25000$ eur. Tyto skutečnosti se promítaly s utlumujícím se efektem i následující dva roky. Jelikož metoda oběživa na tuto skutečnost nijak nereaguje, počítá se optimální množství oběživa s koeficientem 0,196 . Díky vysoké množství peněžních prostředků v neterminovaných vkladech pak optimální množství oběživa bude vysoké, což znamená, že po vyčíslení rozdílu mezi skutečným stavem oběživa a optimálním vypočteným bude minimální, tím pádem poklesne i objem stínové ekonomiky. V upravené metodě, založené na předpokladu, že v posledních 14 letech, kdy se častěji využívá k platbě rychlejší a snadnější bezhotovostní forma, klesá poptávka po hotovosti a analogicky by se mělo snižovat optimální množství oběživa ve formální ekonomice, způsobilo, že šedá ekonomika sice poklesla, avšak pouze o 2,52 p. b. Rozdíl mezi upravenou a původní metodou díky tomu činil $\mathrm{v}$ roce 2002 rovných $8,28 \mathrm{p}$. b. Tento téměř propastný rozdíl se v následujících letech umocňoval a rozevíral jako nůžky.

Dalším rokem, který vyčnívá z trendu je rok 2010, který se opět vyznačuje poněkud vyšším nárůstem neterminovaných vkladů a co víc, poprvé za sledované období kleslo množství oběživa v oběhu ekonomiky. Od roku 2007 se netermínované vklady vyznačují sníženým tempem nárůstu $\mathrm{v}$ důsledku začátku hypoteční krize v USA a následném celosvětovém rozšíření. Přestože podle zprávy tehdejšího viceguvernéra ČNB, Miroslava Singera (2010), byl bankovní sektor $\mathrm{v}$ období této celosvětové hospodářské krize relativně izolovaný a vyznačující se přebytkem likvidity, mírně se snížila důvěra v banky a toto období se vyznačuje mírně zvýšenou poptávkou po hotovosti. Důvodem změny v roce 2010 je obnovení důvěry v ekonomiku a bankovní systém po této krizi a promítnutí do upřednostnění finančních prostředků v bankách než v hotovosti. Zatímco Gutmannův model na tuto situaci reagoval snižením stínové ekonomiky z 5,23 \% na 2,69 \%, tedy reflektoval snížení oběživa plně do snížení stínové ekonomiky, úprava poměru (přestože se taktéž snížil) zapříčinila pokles z 15,44 \% jen na 13,95 \%, což představuje mírnější pokles stínové ekonomiky.

Aby výsledky odhadu získaly na vypovídací hodnotě, je potřeba srovnání s výsledky jiných autorů a za využití odlišných metod. Několik autorů se zabývalo právě odhady stínové ekonomiky pro Českou republiku, avšak jak je patrné z Tabulky 4 a Tabulky 5, odhady jsou často neaktuální a nelze je v mnoha př́padech porovnat $s$ nejnovějšími lety. Dále je důležité upozornit, že se značně liší výsledky nejen u jednotlivých metod výpočtu, ale i v prípadech, kdy dva autoři použijí stejnou metodu. 
Tabulka 4: Odhady stínové ekonomiky různých autorů roky 1999 - 2006 v \%

\begin{tabular}{|l|c|c|c|c|c|c|c|c|}
\hline \multicolumn{1}{|c|}{ Autor a metoda } & $\mathbf{1 9 9 9}$ & $\mathbf{2 0 0 0}$ & $\mathbf{2 0 0 1}$ & $\mathbf{2 0 0 2}$ & $\mathbf{2 0 0 3}$ & $\mathbf{2 0 0 4}$ & $\mathbf{2 0 0 5}$ & $\mathbf{2 0 0 6}$ \\
\hline Fassmann, Kaufmannova metoda & - & 7,7 & - & - & - & - & - & - \\
\hline Fassmann, metodapodílu oběživa & 20,6 & 21,9 & 18,9 & 16,9 & - & - & - & - \\
\hline Palda, Hanousek dotazníkové šetření & 22,2 & - & - & 23,2 & - & 21,4 & - & - \\
\hline Filipec, model poptávky po peněžních & 16,65 & 17 & 17,01 & 18,09 & 16,58 & 16,27 & 16,92 & 17,34 \\
\hline Schneider, DYMIMIC & 19,1 & - & 19,6 & 20,1 & 19,2 & 18,3 & - & - \\
\hline Schneider, MIMIC & 19,3 & 19,1 & 18,9 & 18,8 & 18,7 & 18,4 & 17,8 & 17,3 \\
\hline Autoři práce, metoda podílu oběživa & 20,65 & 21,90 & 18,91 & 9,76 & 8,87 & 7,95 & 8,01 & 6,92 \\
\hline Autoři práce, metoda podílu oběživa po úpravě & 20,65 & 21,90 & 20,56 & 18,04 & 17,55 & 17,01 & 17,05 & 16,43 \\
\hline
\end{tabular}

Zdroj: Fassmann (2003), Hanousek a Palda (2006), Filipec (2011), Schneider (2013), vlastní propočet

Tabulka 5: Odhad stínové ekonomiky různých autorů roky 2007 - 2014 v \%

\begin{tabular}{|l|c|c|c|c|c|c|c|c|}
\hline \multicolumn{1}{|c}{ Autor a metoda } & $\mathbf{2 0 0 7}$ & $\mathbf{2 0 0 8}$ & $\mathbf{2 0 0 9}$ & $\mathbf{2 0 1 0}$ & $\mathbf{2 0 1 1}$ & $\mathbf{2 0 1 2}$ & $\mathbf{2 0 1 3}$ & $\mathbf{2 0 1 4}$ \\
\hline Palda, Hanousek, dotazníkové šetření & - & - & - & - & - & - & - & \\
\hline Filipec, model poptávky po peněžních & 17,85 & 17,22 & 15,71 & - & - & - & - & - \\
\hline Schneider, DYMIMIC & - & - & - & - & - & - & - & - \\
\hline Schneider, MIMIC & 17 & 16,6 & 16,9 & 16,7 & 16,4 & 16 & 15,5 & 15,4 \\
\hline Autoři práce, metoda oběživa & 6,19 & 5,61 & 5,23 & 2,69 & 1,49 & 0,93 & 0,06 & $-0,67$ \\
\hline Autoři práce, metoda podílu oběživa po úpravě & 16,01 & 15,67 & 15,44 & 13,95 & 13,23 & 12,89 & 12,37 & 11,93 \\
\hline
\end{tabular}

Zdroj: Fassmann (2003), Hanousek a Palda (2006), Filipec (2011), Schneider (2013), vlastní propočet

\section{Závěr}

V rámci př́spěvku bylo provedeno vlastní měření odhadu šedé ekonomiky v České republice a to s využitím Gutmannova modelu avšak s výraznou změnou v důsledku kritiky této metody autory zmíněnými výše. K odhadu velikosti šedé ekonomiky existuje nespočet metod, přičemž každá $z$ nich je založena na několika předpokladech a $v$ návaznosti na tyto skutečnosti jsou následně podrobeny kritice z odborných kruhů. Jednou z často využívaných metod je metoda poměru oběživa (zmíněná Gutmannova metoda), jejíž nevhodnost se předpokládá především pro transformující se ekonomiky v důsledku rozvoje bankovní sféry. Analýza vývoje bankovní sféry byla zahrnuta i do předmětu tohoto článku, aby bylo následně možné identifikovat a diskutovat nedostatky této metody v základním výkladu. V návaznosti na kritiku této metody pro Českou republiku byla provedena úprava, která částečně napravila její nedostatky. Tato modifikace spočívala zejména $\mathrm{v}$ úpravě optimálního poměru oběživa k jednodenním vkladům, který je pro odhad stínové ekonomiky klíčový. Vycházela z rozmachu bezhotovostních plateb v ČR v roce 2001, který se odráží v neustále se snižující potřebě hotovostní formě peněz. Pokud bychom v této souvislosti vyšli z Friedmanova pravidla konstantního růstu peněžní zásoby lze předpokládat, že v ekonomice je přirozený růst oběživa i jednodenních vkladů v čase. Ústup od hotovostních transakcí by se pak měl projevit ve vyšším růstu jednodenních vkladů ve srovnání s oběživem. Rozdíl růstu těchto dvou peněžních ukazatelů představuje preferenci bezhotovostní formy peněz, která je následně využívána k platbám, což by se mělo promítnout do snížení optimálního poměru oběživa. Lze předpokládat, že tato jednoduchá úprava metody poměru oběživa napomohla ve zreálnění odhadu stínové ekonomiky proti její původní verzi.

Abstrahujeme-li od skutečnosti, že neformální ekonomika je prováděna i bezhotovostní formou úhrad, je poměrně známá a nevyvratitelná skutečnost, že podstatná část těchto aktivit je páchána za pomoci hotovosti. Především se týká práce na černo a nehlášení př́ijmů. Touto problematikou v rámci České republiky se zabývala i společnost Visa (2015) ve spolupráci s profesorem Schneiderem. Podle ní představuje největší problém zpracovatelský průmysl, 
kdy se odhaduje, že až $50 \%$ výdělků zaměstnanců zprostředkovávaných pracovními agenturami neodpovídá skutečné úrovni. Mezi další problematické odvětví se řadí taxislužby, hotely a restaurace vyznačující se neposkytováním účtenek či autobazary, jejichž oficiální hodnoty transakcí jsou nižší, přičemž rozdíl mezi ní a skutečnou cenou vyplácí v hotovosti na ruku. V těch př́padech je tedy na místě uvažovat o silné korelaci mezi stínovou ekonomikou a bezhotovostní formou plateb, což potvrzuji i zmiňovaná studie. Podle simulace velikosti stínové ekonomiky s nezměněnými vstupními faktory kromě elektronických plateb, jejíž výsledky jsou součástí zprávy, navýšení počtu elektronických plateb o $5 \%$ vede ke snížení stínové ekonomiky o 2-3\%. Je nutné připomenout, že v případě vlastních výpočtů výše stínové ekonomiky se nejedná o zcela exaktní vědu a při hodnocení výsledků by to čitateli mělo zůstat na paměti.

\section{Literatura}

[1] ARAD, 2016. Veřejná databáze České národní banky. [online]. [vid. 15. ř́́jna 2016]. Dostupné z: http://www.cnb.cz/docs/ARADY/HTML/index.htm

[2] BAYAR, Y., 2016. Public governance and shadow economy in Central and Eastern European countries. Administration and Public Mangement Review. 27, 62-73. ISSN 1583-9583.

[3] ČESKÁ NÁRODNÍ BANKA, 2003. Záznam z jednání bankovní rady ČNB ze dne 27. února 2003. [online]. [vid. 5. prosince 2016] Dostupné z: http://www.cnb.cz/cs/menova_politika/br_zapisy_z_jednani/2003/CMOM_030227.html

[4] FASSMANN, M., 2007. Stínová ekonomika IV: Boj proti stínové ekonomice. Praha: Sondy. ISBN 80-86846-18-0.

[5] FASSMANN, M., 2003. Stínová ekonomika II: Stínová ekonomika v České republice. Praha: Sondy, bez ISBN.

[6] FILIPEC, P., 2011. The Shadow Economy Analysis. Praha: Bakalářská práce, VŠE.

[7] FINANČNÍ SPRÁVA, 1999-2013. Informace o činnosti Finanční správy 1999-2013. [online]. [vid. 15. záŕi 2015]. Dostupné z: http://www.financnisprava.cz/cs/financnisprava/financni-sprava-cr/vyrocni-zpravy-a-souvisejici-dokumenty/2013

[8] HANOUSEK, J. a F. PALDA, 2006. Předem odsouzeno k neúspěchu: Měření šedé ekonomiky tranzitivních zemi pomoci makroekonomických metod. Politická ekonomie. (2), 190-202. ISSN 0032-3233.

[9] JÍLEK, J., 1998. Korupce, praní peněz a oběživo. Hospodářské noviny [online]. [vid. 14. června 2016]. ISSN 1213-7693. Dostupné z: http://archiv.ihned.cz/c1-969539-korupceprani-penez-a-obezivo

[10] POSLANECKÁ SNĚMOVNA PARLAMENTU ČESKÉ REPUBLIKY, 1994. Zpráva vlády o plnění státního rozpočtu České republiky za 1. čtvrtletí 1994. [online]. [vid. 16. července 2016]. Dostupné z: http://www.psp.cz/eknih/1993ps/tisky/t1391_01.htm

[11] SBK, 2016. Souhrnné statistiky. [online]. [vid. 15. záři 2016]. Dostupné z: http://www.bankovnikarty.cz/pages/czech/profil_statistiky.html

[12] SCHNEIDER, F. and C. C. WILLIAMS, 2013. The shadow economy. Institute of Economic Affairs [online]. 186 s. [vid. 15. záŕi 2016]. ISBN 978-025-5366-748. Dostupné z: http://papers.ssrn.com/sol3/papers.cfm?abstract_id=2286334

[13] SINGER, M., 2010. Hospodářská krize a česká ekonomika. [online]. [vid. 25. října 2016]. Dostupné z: www.cnb.cz/cs/verejnost/pro_media/.../singer_20100614_vse.pdf 
[14] SOUKUP, J. et. al., 2007. Makroekonomie: moderní př́istup. 1. vyd. Praha: Management Press. ISBN 978-80-7261-174-4.

[15] SURGA, L., 2004. Jak dál v hotovostním peněžním oběhu. [online]. [vid. 18. října 2016]. Dostupné https://www.cnb.cz/cs/verejnost/pro_media/clanky_rozhovory/media_2004/cl_04_04021 9a.html

[16] VISA, 2013. The shadow economy in Europe 2013. [online]. [vid. 5. srpna 2016]. Dostupné $\quad \mathrm{z}$ : $\quad \mathrm{http}: / / \mathrm{www}$.atkearney.com/financial-institutions/featured-article//asset_publisher/j8IucAqMqEhB/content/the-shadow-economy-in-europe-2013/10192

[17] VISA. 2015. Šedá ekonomika v České republice. [online]. [vid. 18. listopadu 2016]. Dostupné http://www.visa.cz/media/pdf/Visa_Seda\%20ekonomika\%20v\%20CR_studie_30_1_201 5.pdf 